\author{
Ewa Kochańska \\ Research and Innovation Centre Pro-Akademia \\ Innowacyjna 9/11, 95-050 Konstantynow Lodzki, Poland, ewa.kochanska@proakademia.eu \\ (D) https://orcid.org/0000-0002-4735-7969 \\ Iwona Adamkiewicz \\ Research and Innovation Centre Pro-Akademia \\ Innowacyjna 9/11, 95-050 Konstantynow Lodzki, Poland, iwona.adamkiewicz@proakademia.eu \\ (D) https://orcid.org/0000-0003-2272-802X \\ Lais Bertozo \\ FIEC System - Federation of Industries of the State of Ceará System \\ Av. Barão de Studart, 1980, Aldeota, Fortaleza, Brazil, lbertozo@sfiec.org.br
}

\title{
SELECTED PROBLEMS OF WATER, ELECTRICITY AND WASTE MANAGEMENT IN BRAZIL IN THE CONTEXT OF ITS IMPACT ON CLIMATE CHANGE MITIGATION
}

\begin{abstract}
The article discusses selected problems related to environmental protection in the context of climate change in the Ceará region of North-Eastern Brazil. The authors analyse the lack of water and negative impact of climate change on fish processing in the region. Also, the opportunity to use fish waste to increase profitability of the local fish processing SMEs thanks to implementation of climate-friendly technologies such as the production of fertilisers and energy for their own needs is discussed.
\end{abstract}

\section{Key words}

environmental protection, climate change, waste and water management, Brazil

\section{Introduction}

There is a close relationship between development of civilization based on new technologies, increasingly complex systems of society organization and the progressive exploitation of the natural environment, and as a consequence, climate change.

\section{Method of research}

The main research method was content analysis and a bibliographic search. This made it possible to conduct a sensible analysis of the phenomenon of climate change caused by economic development, which is manifest in the growing amount of waste, including organic waste as well as the increasing demand for electric energy under conditions of continually decreasing yearly rainfalls and ongoing lowering of the groundwater level. The database for the research was based on official statistical data of Brazilian state and regional institutions such as the FIEC System (Federation of Industries of the State of Ceará System), international organizations, reference publications, analytical monographs, annual statistical bulletins, reports of world organizations, the European Union and Brazilian institutions and authors' own research. Field research was performed and information collected from PISCIS, a small Brazilian company typical of the area under study, specializing in fish processing. To obtain quantitative data at the regional level and to calculate the impact of implementation of waste-toenergy technology for mitigation of negative effects of climate change, mathematical modelling was used. The evolutionary features of the dependence of economic development on a local scale as well as climate change was taken into consideration. Multi-parameter modelling was used to calculate the impact of the use of wasteto-energy technology on PiSCIS's development.

The general research methods used were specific to positive economics. The main paradigm of positive economy is to explain economic phenomena based on objective knowledge of reality and to present empirical data and analyse the effects of changes in economic conditions or variants of economic policy without formulating value judgments. Positive economics focuses on developing the most universal tools and methods of economic analysis in order to generalize economic processes and economic mechanisms as comprehensively as possible. These 
include description, comparison, statistical review, system analysis, results of field research, case analysis and others that help to characterize the development of this phenomenon in a more comprehensive manner.

\section{Results}

\section{Water management in Brazil in the context of mitigation of climate change effects}

Climate change, and especially the progressing water shortage in the Ceará region and Jaguaribara basin have a direct economic and social impact on the development processes in general and on the business of many companies located in this region, especially on the production of a various range of agricultural and fish products, e.g. tomatoes or viscera fish oil. The State of Ceará is one of the driest in Brazil. The rainfall in this region takes place from January to June and is at an average level of $400 \mathrm{~mm}$ in the interior to $1,200 \mathrm{~mm}$ on the coast. Figure 1 shows the state of Jaguaribara river and Castanhão reservoir in 2012.

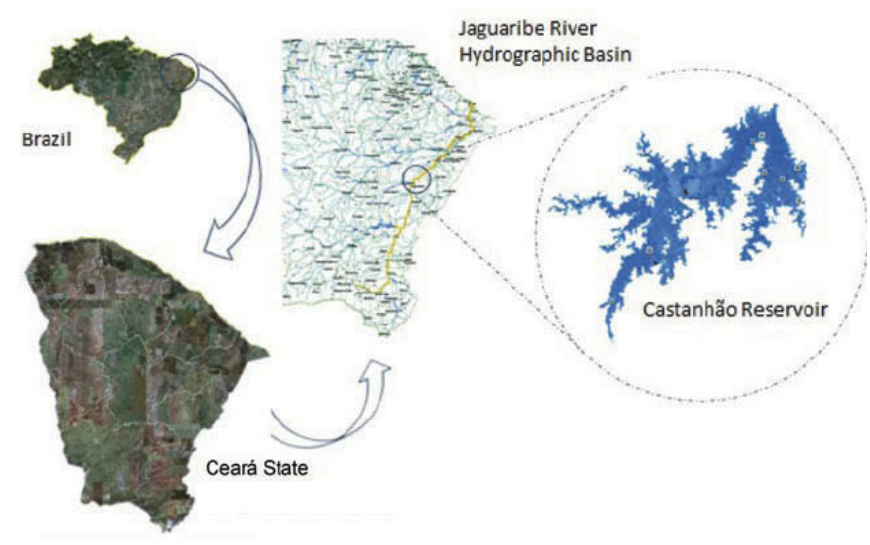

Figure 1. Map of the Castanhão Reservoir in the Jaguaribe River basin, Ceará State, Brazil [1]

Brazil may be experiencing its worst drought cycle in over a century as the region braces itself for its $7^{\text {th }}$ consecutive year of insufficient rainfall. Almost $100 \%$ of the region has been affected by severe droughts, and half of the Northeastern cities, including Fortaleza and Jaguaribara, have declared states of emergency. The last time the region experienced six consecutive years of drought was between 1979 and 1983, but even then, it rained more than now.

Water management comes first in the list of problems to be solved by the state. The most important issues associated with low rainfall and high temperatures are thin soils hindering water storage, high evapotranspiration and a large rural population that is dependent on intensive fish production. In response to the deteriorating situation of water management, tanks with a total capacity of $13,560 \mathrm{~m}^{3}(4,700$ tanks) were installed throughout the country in which water from the rainy season is stored. [2].

Another example of the water crises is the effect on the rapidly growing Fortaleza, the largest city of Ceará, which does not have large water reservoirs and it is necessary to transfer water to the city from the nearby Jaguaribe basin. Frequent and devastating drought and economic activity have caused the Jaguaribe basin itself to require intensive intervention by the construction of large water reservoirs. In 2003, the Castanhão reservoir with a capacity of $6,700 \mathrm{~m}^{3}$ was built [3] Castanhão's construction provides flood protection in the river basin and temporary storage for the proposed inter-base transfer from the São Francisco River [4]. Complementary to Castanhão are two additional main tanks in the pool, such as Orós $\left(1,940 \mathrm{~m}^{3}\right)$ and Banabuiú $\left(1,601 \mathrm{~m}^{3}\right)$. Together, these 3 reservoirs account for over $75 \%$ of the basin's storage capacity of the state (Figure 2 ). 


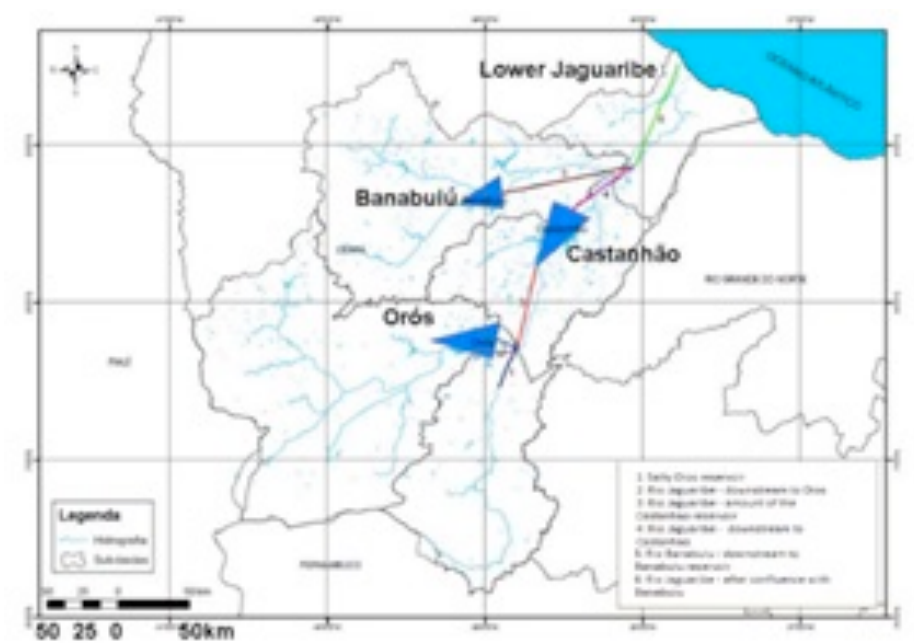

Figure 2. Map of the Jaguaribe basin and the three main reservoirs and rivers [5]

Brazil's semiarid region is the most densely populated semi-dry region in the world. Long-lasting droughts have had a significant negative impact on the social and economic aspects of this part of the region, therefore, preventive actions have been taken, such as damming the rivers and construction of water reservoirs in order to neutralize the effects of prolonged drought. Despite these efforts, in 2019 reserves of only $3.75 \%$ capacity were registered in Açude Castanhão.[6]. The problem is not only the amount of water but also the deterioration of the water's quality due to increasing concentrations of dissolved salts and decreasing oxygen levels (Figure 3).

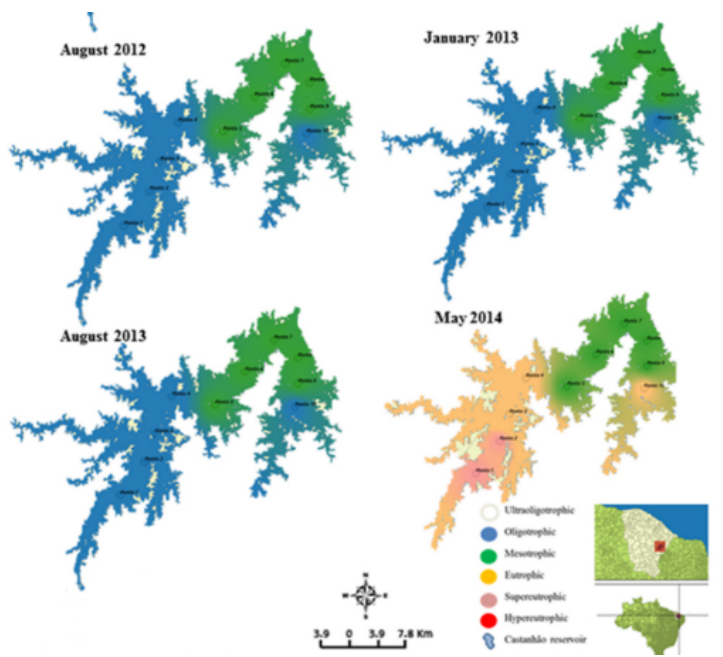

Figure 3. Trophic state index changes in the Castanhão reservoir in NE Brazil, during the period of Nov. 2011 - May 2014 [7]

Another side to the problem is the increased frequency and intensity of extreme rainfall which causes augmented nutrient inputs from the watershed. In the Ceará region, the amount of annual rainfall has been steadily decreasing, which has resulted in an increase in the frequency and duration of extended periods of drought which in turn has led to nutrient accumulation, increase of algal density and frequency of cyanobacteria blooms, thus rendering these systems much more vulnerable to eutrophication. This has had a negative effect on the tilapia population in Açude Castanhão and has resulted in loss of fish valued at 18 million Brazilian Reals (approx. USD $4.3 \mathrm{mln}$ ) [8]. These occurrences confirm changes in the climate and emphasize the need to take them into account as significant drivers with impact on the environmental and socio-economic conditions of the company's development. 


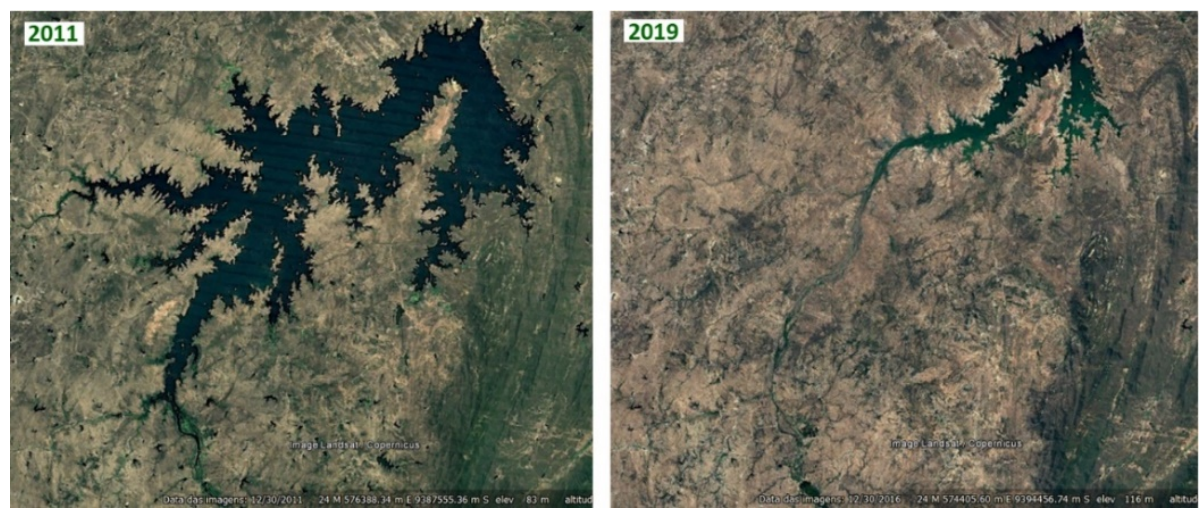

Figure 4. Satellite pictures of the Castanhão reservoir 2011 and 2019 [9]

Therefore, tilapia production has suffered a significant reduction [8] and consequently the production of oil from fish viscera has been considerably reduced as well. Drought periods during following years besides having reduced the tilapia population, have also resulted in the concentration of potential pollutants in Açude Castanhão. The installation of the PISCIS company in the Ceará region is an example of intensively developing fish cage/container aquaculture, which negatively affects water quality, in particular during extended drought periods. PISCIS company / PISCIS Industry Trade LTDA is a good example of a business entity operating in the Ceará Region, which has been forced to change their production profile due to climate change.

PISCIS was founded in 2009 by a private entrepreneur. In the beginning, the company worked with small volumes of fish waste (viscera of tilapia), however, with the expansion of tilapia production activity in the region, the company quickly grew and PISCIS processed ca. 8 tonnes daily of tilapia viscera collected from local fisheries of Açude Público Padre Cícero commonly known as Açude Castanhão. In the following years, the company became well known regionally and nationally for the transformation of tilapia residues into oil and received various local and national awards for sustainable development. In parallel, the company established itself on the market with the commercialisation of viscera oil for animal feed industries. In addition, it sold oil to Petrobras Biocombustível from Quixadá to produce biodiesel [2]. The progressive growth of PISCIS was also possible due to the continuous increase in prices for viscera oil (Figure 5).

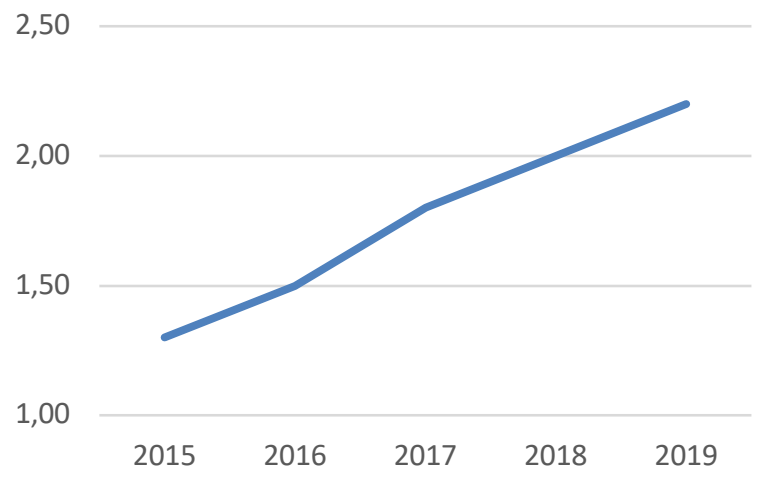

Figure 5. Prices of viscera oil (RS/L) [10]

Additionally, during the same period, the company started a new project that would help fish farming of tilapia in a sustainable way. Tilapia is the most popular fish in Brazil and Nile tilapia (Oreochromis niloticus) is one of the most readily available varieties in the country. During 2015, some 219,000 tonnes were caught (slaughtered and sold) [4]. This number had increased by $9.7 \%$ compared to 2014 and almost 10 times more since 1998 when 30,000 metric tons were sold. The largest producing regions are in Ceará, mainly in the municipality of Jaguaribara. However, from 2015, Castanhão region has been affected by drought and, consequently, the activity of tilapia production declined, and the production of oil diminished as well. In PISCIS aquaculture the strong influential factors are the cost of feed (accounting for $60 \%$ of the total production cost) and the most limiting factor is the lack of water availability. High stocking density and rearing of aquatic fish and shrimp requires wastewater treatment. Because of the water situation and wastewater treatment requirements, while waiting 
for rebuilding of natural water reservoirs, the company has diversified the production and has been investing in the production of shrimp and tilapia by water container technology using a biofloc system (Figure 6)
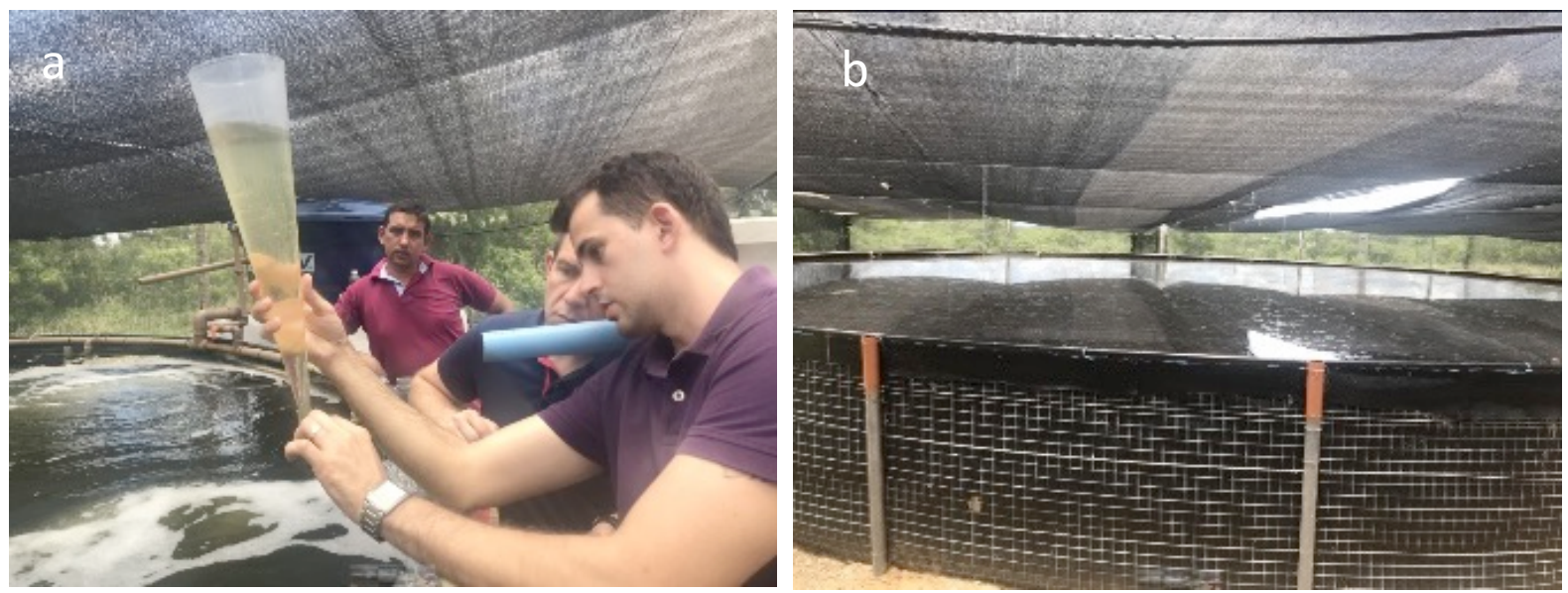

Figure 6. Biofloc technology used by PISCIS: a) evaluation of water quality, b) fish farming container

Biofloc is a wastewater treatment technology that enhances water quality by balancing nitrogen and carbon in the system and which has gained vital importance as an approach in aquaculture. Thanks to this technical solution, there is no direct dependency on the Castanhão water, and waste water is minimal. The Biofloc system has been developed to save and effectively manage water and to improve environmental control over aquatic fish and shrimp production. PISCIS fish farming activity is based on water containers ( $1 \mathrm{~m}$ height, $30 \mathrm{~m}$ diameter). The biofloc technology provides many benefits: water use efficiency, reduction of environmental impact, limited or zero water exchange, higher productivity of fish and thanks to feed conversion in the eco-friendly culture systems of fish and shrimp as well as provides higher biosecurity. However, there is one serious disadvantage, namely biofloc increases energy demand for mixing and aeration of the pools [11]. Currently PISCIS company has capacity to process 8 tonnes of fish per day. In the future, they plan to produce ca. 174 tonnes per year [10]. Time needed to grow one batch of fish under standard conditions is approximately 6 months. PISCIS farms currently produces $8 \mathrm{~kg}$ of aquaculture per $1 \mathrm{~m}^{3}$ of containers, but in the future, thanks to implementation of more effective system operation, it is expected that the productivity is going to increase to $30 \mathrm{~kg}$ per $1 \mathrm{~m}^{3}$ of containers. Therefore, there are numerous opportunities related to the effective use and potential of fish farming [12]. Special support is expected from the EU, within the Low Carbon Business Action Brazil Programme and transferring of the European technologies.

\section{Waste management in Brazil in context of mitigation of climate change effects}

The main challenge of waste management worldwide for the coming years is the transition to a circular economy, which aims to use the unavoidable waste produced as a resource by recycling and upcycling processes that minimise the amount of waste generated. In Europe, positive trends in waste management can be observed because of an increasing level of waste recycling as well as the reuse and simultaneous decrease in the amount of waste generated. For example, at the beginning of this century, the amount of waste generated in Poland (excluding municipal waste) was 130 million tonnes. In 2017, approximately 114 million tonnes were generated that indicates a decrease of approximately $10 \%$. The amount of waste generated annually has remained at a similar level, while the GDP has been constantly growing.

As the fifth largest waste producer in the world, Brazil faces major waste management challenges. Every day, 198,000 tons of municipal waste is produced, of which about $58 \%$ ends up in sanitary landfills, $24 \%$ in controlled landfills, and $17 \%$ goes to various landfills. It is especially necessary to solve the problem of the other $42 \%$ of waste that goes to unknown places that lack proper systems and procedures necessary to protect the environment from damage and degradation. Brazil lacks adequate social support as well as necessary infrastructure expenditure and the necessary political will to implement new regulations. Improper disposal practices continue to be common practice in all Brazilian states [13]. In 2010, Brazil implemented a national solid waste policy. Its main goal was to reduce the total amount of waste generated at a national level, as well as to increase sustainable solid waste management through activities such as:

- incentives for the recycling industry; 
- promotion of social inclusion;

- non-generation, reduction, reuse, recycling and solid waste treatment;

- intensification of environmental education actions;

- rationalisation of natural resources in the production of new items;

- technical capacitation;

- appropriate final disposal of waste;

- clear channels set up between the different classes of government agencies and between them and the business sector, aimed at technical and financial cooperation.

Regulations regarding waste include types of waste such as: public, domestic, industrial, mining, agroforestry, transportation, construction, and health industries waste. Responsibility for paying for or providing management of waste now falls on its producers.

The Low Waste regulation also mandated:

- solid waste plans to be prepared by all 5,570 municipalities in the country by 2012;

- closure of all dumpsites by 2014;

- reduction of organic waste by $53 \%$;

- increase in recycling of $45 \%$;

- raising waste-to-energy production to $300 \mathrm{MWh}$ by 2031;

- social inclusion of $75 \%$ of waste pickers by 2031 .

As of now, the country lags far behind all these targets. For instance, only $40 \%$ of municipalities had submitted Solid Waste Management (SWM) plans by 2015 and approximately 3,000 dumpsites are still open, mostly in the North, Northeast and Midwest regions. To achieve the reduction of carbon dioxide associated with landfill waste and protect the environment from human-generated waste, it is necessary to improve the overall recycling rate, which is currently at $6 \%$, whereas the target for 2030 is $45 \%$. However, an analysis of the way Brazilians deal with waste management problems, including the technical and organisational processes and the need to change social perception of waste as a valuable resource, one may come to the conclusion that it will take a long time. The Brazilian waste management budget is very low at 3 euros per month per inhabitant, which can be compared to cities like Barcelona - 19 euros or Tokyo at 43 euros. [15].

Major infrastructure investments are needed. Sanitary landfills are the most popular destination of waste in Brazil: nearly $60 \%$ of all kinds of waste are isolated from the environment in sanitary landfills. It is worth noting that only $23 \%$ of them are controlled. Needless to say, the present-day situation of waste management in Brazil is challenging (Table 1, Table 2).

Table 1. Final destination of waste in Brazil in 2016 and 2017 [16]

\begin{tabular}{|c|c|c|c|c|c|}
\hline \multicolumn{2}{|c|}{ Sanitary Landfill } & \multicolumn{2}{c|}{ Controlled Landfill } & \multicolumn{2}{c|}{ Open air dumps } \\
\hline 2016 & 2017 & 2016 & 2017 & 2016 & 2017 \\
\hline $59 \%$ & $59.1 \%$ & $23.5 \%$ & $22.9 \%$ & $17.5 \%$ & $18 \%$ \\
\hline
\end{tabular}

Table 2. Number of cities: by type of final disposal in 2016 [16]

\begin{tabular}{|l|c|c|c|c|c|c|}
\hline Type of disposal & Brazil & North & Northeast & Midwest & Southeast & South \\
\hline Sanitary Landfill & 2239 & 90 & 449 & 159 & 817 & 703 \\
\hline Controlled Landfill & 1772 & 108 & 484 & 159 & 634 & 357 \\
\hline Open air dumps & 1559 & 252 & 861 & 149 & 217 & 131 \\
\hline TOTAL & 5570 & 450 & 1794 & 467 & 1668 & 1191 \\
\hline
\end{tabular}

The Ceará region has begun implementing a recycling program to reduce waste in landfills. A good example is the city of Fortaleza, where in 2016 the implementation of a recycling strategy based on social values and actions aimed at changing the behavior of residents was undertaken. Transport and energy credits have been proposed for residents of 24 districts who properly segregate waste. The campaign covered 9,000 residents and 830 tons of waste were recycled, thus reducing landfills. The next planned step is to introduce the program to another 100 districts. As more than $50 \%$ of solid waste in Brazil constitutes organic waste, it provides a natural base for promoting bioenergy and biogas production development [17]. 


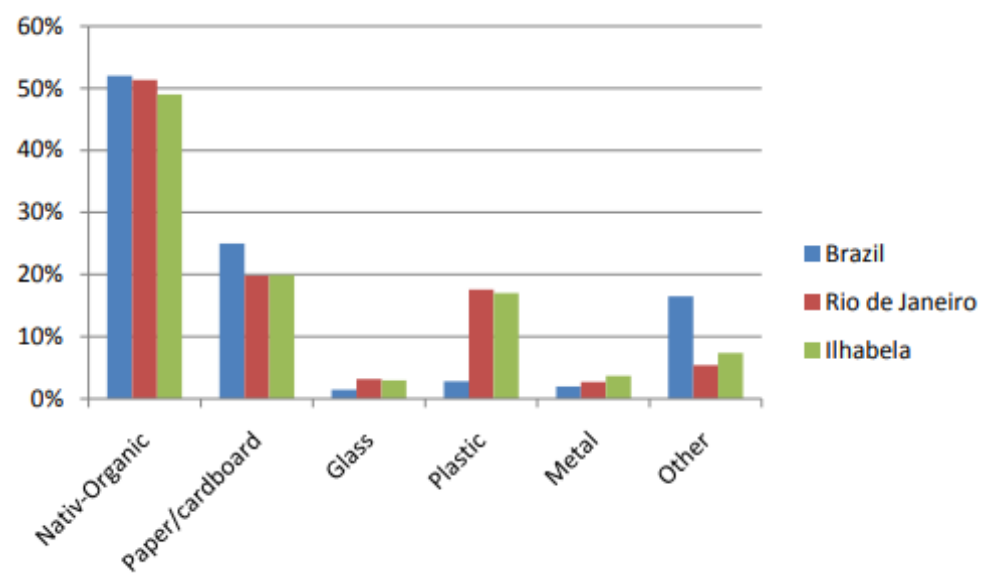

Figure 7. Composition of solid waste in selected Brazilian cities [17]

Energy management in Brazil in the context of mitigation of climate change effects

Brazil has been one of the largest energy consumers in the world for decades. In 2017, it took 8th place, and economic growth generates a further increase in primary energy consumption. The installed generating capacity in 2017 was $157 \mathrm{GW}$ and increased by 4.5\% compared to 2016 [18]. The country remains dependent on two sources of energy: natural gas and hydro energy. In June 2017, the installed power of renewable sources was $100 \mathrm{MW}$ from photovoltaics (PV), up from about $1 \mathrm{MW}$ in 2012. The government expects Brazil's overall solar capacity to exceed $8 \mathrm{GW}$ by 2024. As of December 2018, wind power plants reached an installed power of 14.2 GW.

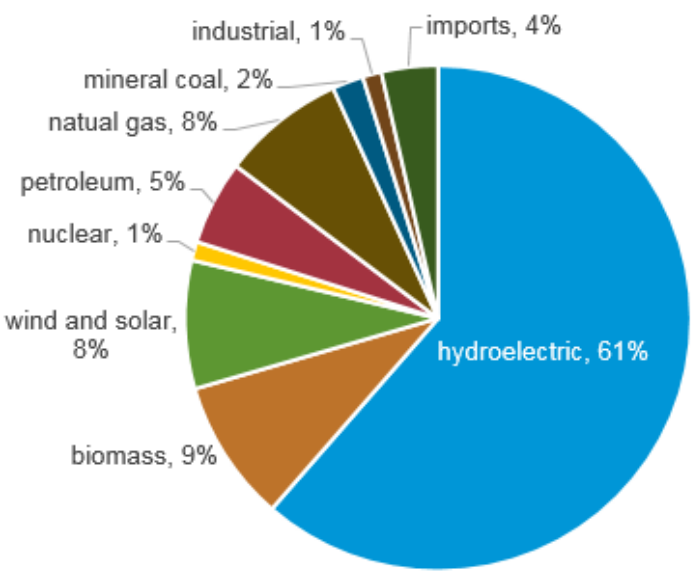

Figure 8. Power generation supply in 2017 [19]

Hydropower accounts for a high share of Brazil's energy mix and amounts to $60.8 \%$. Climate change will therefore have a major impact on their operation and limits the possibility of increasing their share as a security for Brazil's energy system. In addition to climate change, Brazil's water potential is seriously affected by such factors as agricultural intensification, industrial development and urbanization. During 2014-2016, a serious water crisis occurred in the Southeast as a result of chronic drought. Since 2014 these factors have caused a decrease in energy produced from this source. This crisis was accompanied by an increase in energy production from sources such as fossil fuels, wind, solar and biogas [20]. Wind and solar energy technology development are challenging, however, despite the favorable natural conditions (areas with high solar irradiation and areas with good wind capacity) use of these sources is insufficient, showing a clear need for more investment. In addition, most of the equipment required for the installation of photovoltaics, concentrated solar thermal plants or wind energy plants have to be imported, which implies high costs. The Brazilian Electricity Regulatory Agency distinguishes the following types of biomass: municipal solid waste (UW), agro-industrial waste (AIW), forest residues, animal waste (AW). Biogas plants are responsible for only $9 \%$ of electricity production in Brazil, which means the operation of 127 biogas plants using, among others, agricultural residues. In 2016, the installed biogas production capacity was $450 \mathrm{MW}$ [18]. No biogas plant is located in the Ceará region (Figure 9). 


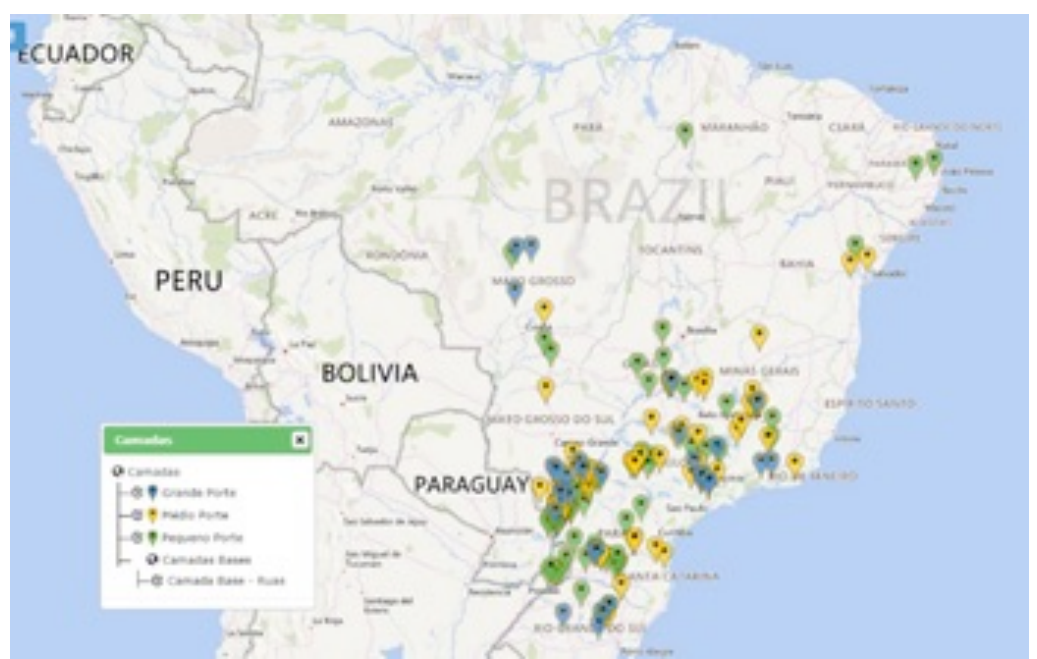

Figure 9. Map of generation centres of biogas production in Brazil [21] The blue, yellow and green markers indicate the unit size, classified as large (more than $12000 \mathrm{~m}^{3} /$ day), medium (from 2000 to $12000 \mathrm{~m}^{3} /$ day) and small size (less than 2000 $\mathrm{m}^{3} /$ day), respectively.

While in Brazil energy is generated from an increasing variety of energy sources, the average cost of energy bills has increased. Between 2012 and 2017, the average energy cost in the country increased by 53\%, which is 12\% above the inflation rate. The electrical energy tariffs in Brazil are somewhat complex. The current energy prices in the state of Ceará are presented below, according to the supply of voltage [22]:

For low voltage consumers (below $75 \mathrm{~kW}$ of installed power), there is a monomial tariff of $0.1678 \mathrm{EUR} / \mathrm{kWh}$, including taxes and charges. For public lighting supply, the tariff is $0.098604 \mathrm{EUR} / \mathrm{kWh}$. For the 836,002 lowincome consumers ( $23.7 \%$ of total), with an annual consumption of $1,069,998.58 \mathrm{MWh}$, their tariff is subsidised by the other consumers, according to the following rule:

- Monthly consumption between $30 \mathrm{kWh}$ and $100 \mathrm{kWh}=>65 \%$ tariff reduction

- Monthly consumption between $100 \mathrm{kWh}$ and $220 \mathrm{kWh}=>10 \%$ tariff reduction

- Monthly consumption above $200 \mathrm{kWh}=>$ no tariff reduction

Other consumer categories that can have subsidies as well:

- Aquaculture and irrigation: $60 \%$ to $73 \%$ tariff reduction

- Water-sewage utility: $15 \%$ of energy tariff reduction.

For high voltage consumers (from $2.3 \mathrm{kV}$ to $25 \mathrm{kV}$ and above $75 \mathrm{~kW}$ of installed power), there are binomial (power and consumption tariffs) and seasonal (according the daily peak demand) tariffs, as shown in essential terms as follows (green tariff):

- Peak consumption period $=0.411 \mathrm{EUR} / \mathrm{kWh}$

- Off-peak consumption period $=0.101 \mathrm{EUR} / \mathrm{kWh}$

- Use of distribution system $=4.76 \mathrm{EUR} / \mathrm{kW}$

Some consumers are allowed subsidies:

- Rural consumers: $10 \%$ of power demand and $10 \%$ of energy tariff

- Aquaculture and irrigation: $70 \%$ to $90 \%$ tariff reduction

- Water-sewage utility: $15 \%$ for power demand and $15 \%$ of energy tariff

- Free Energy Market using renewable sources: $50 \%$ of power demand tariff.

Between 2014 and 2018, the electrical energy prices in Ceará state for low and high voltage consumers increased by $35 \%$ and $54 \%$, respectively.

Table 3. Energy demand in in Ceará state [22], [23]

\begin{tabular}{|c|c|c|c|c|}
\hline $\begin{array}{c}\text { Low Voltage } \\
\text { (residential) }\end{array}$ & $\begin{array}{c}\text { TUSD1) } \\
(\mathrm{R} \$ 2) / \mathrm{kWh})\end{array}$ & TE3) $(\mathrm{R} \$ / \mathrm{kWh})$ & Energy $(\mathrm{R} \$ / \mathrm{kWh})$ & Growth (\%) \\
\hline 2018 & 239,36 & 253,09 & 492,45 & 4,0 \\
\hline
\end{tabular}




\begin{tabular}{|c|c|c|c|c|}
\hline 2017 & 225,05 & 248,64 & 473,69 & $-0,3$ \\
\hline 2016 & 224,23 & 251,04 & 475,27 & 13,7 \\
\hline 2015 & 193,94 & 224,02 & 417,96 & 16,4 \\
\hline 2014 & 184,12 & 175,1 & 359,22 & \\
\hline
\end{tabular}

*without taxes and charges

Increase in the Energy Tariff - five years 37\%

Rate exchange (R\$ to EUR) 4.35 05/04/2019

1)TUSD - Tariff of Use of Distribution System

2) $R \$$ - current Brazilian currency (Reals)

3)TE - Tariff of Energy

Table 4. Energy prices in 2014-2018 [22]

\begin{tabular}{|c|c|c|c|c|c|c|}
\hline $\begin{array}{l}\text { High } \begin{array}{l}\text { Voltage } \\
\text { (commercial and } \\
\text { industrial) }\end{array} \\
\end{array}$ & $\begin{array}{c}\text { TUSD } \\
(\mathrm{R} \$ / \mathrm{kWh})\end{array}$ & Growth (\%) & $\begin{array}{c}\text { TUSD } \\
\text { (R\$/kWh) }\end{array}$ & $\begin{array}{c}\text { TE } \\
(\mathrm{R} \$ / \mathrm{kWh})\end{array}$ & $\begin{array}{c}\text { Energy } \\
\text { (R\$/kWh) }\end{array}$ & $\begin{array}{c}\text { Growth } \\
\text { (\%) }\end{array}$ \\
\hline 2018 & 13,59 & 13,5 & 36,41 & 240,25 & 276,66 & 4,8 \\
\hline 2017 & 11,97 & 22,1 & 26,45 & 237,44 & 263,89 & $-3,5$ \\
\hline 2016 & 9,8 & 6,6 & 34,07 & 239,46 & 273,53 & 12,6 \\
\hline 2015 & 9,19 & 74,4 & 29,89 & 212,93 & 242,82 & 34,9 \\
\hline 2014 & 5,27 & & 13,7 & 166,34 & 180,04 & \\
\hline
\end{tabular}

*Green tariff

* without taxes and charges

*off-peak

Increase in the TUSD - 5 years (use of Power Distribution System) $158 \%$

Increase in the Energy Tariff - five years

$54 \%$

Rate exchange (R\$̦ to EUR) $\quad 4.35 \quad 05 / 04 / 2019$

An annual revision of the energy tariff is planned with the prospect of an increase in energy tariffs of $8.62 \%$ in 2019.

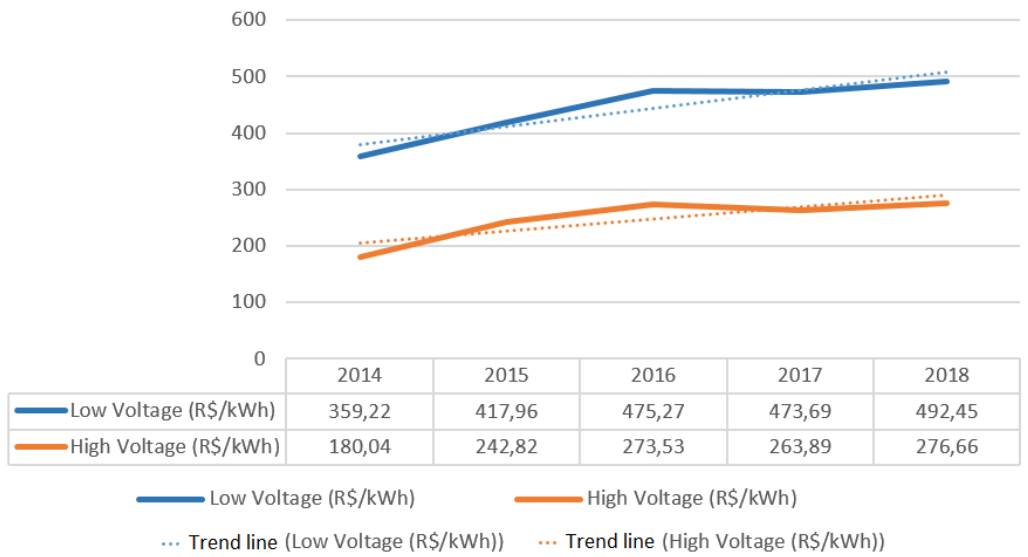

Figure 10. Energy prices for low voltage (residential) and high voltage (commercial and industrial)

The energy taxes and charges applied in electrical energy tariff in Ceará State are $27 \%$ of ICMS (Ceará State Tax) and $6.5 \%$ of PIS and COFINS (Federal Taxes). The exception are low-income consumers that are exempt from taxes unless they reach $140 \mathrm{kWh}$ of consumption per month. The breakdown of the tariff is shown in Figure 11.Figure 11 


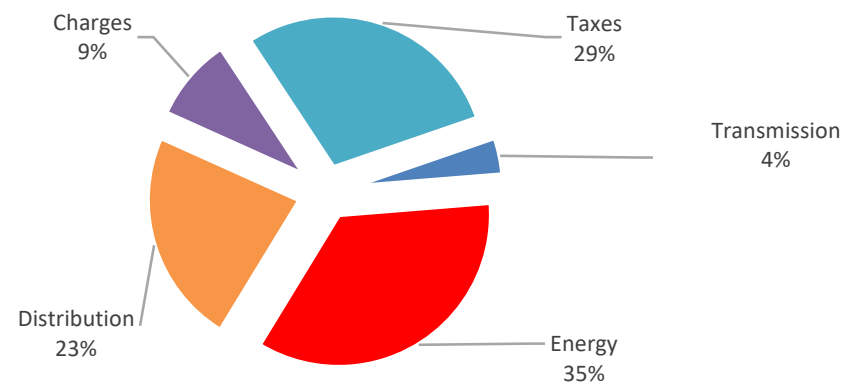

Figure 11. Ceará's electrical energy tariff cost structure [21]

\section{Water and waste management in Brazil's Ceara Region in context of its impact on mitigation of climate change effects}

Waste to energy projects (WtE) usually involve utilisation of waste, including organic waste, to recover energy that can be available in the form of electricity, fuel or any other by-products. The main environmental benefit obtained from biogas plants is a major contribution to a decrease in air pollutants and GHG emissions in the atmosphere. This is possible through the controlled capture of methane, replacement of fossil fuels with biogas and the $\mathrm{CO}_{2}$ emissions that are avoided [24]. The process at a typical WtE biogas plant creates some residues that have to be monitored and accordingly treated to avoid any harmful effects it may have on the environment. The specific residues of the previously mentioned company PISCIS - fish waste - may be converted to electricity and useful by-products such as fertiliser for agriculture. In the context of the negative effects of climate change, droughts and lack of water, specific problems arising from waste management and particularly the high costs of electricity in the northeast of Brazil, the use of organic waste can be a way to mitigate all of the above problems.

\section{Uncertainty and impact of research results on science, economy, environment and society}

To limit the negative impact of climate change in the Ceara Region, the wide implementation of waste management to local SMEs, should be taken into consideration, for such companies as PISCIS. As a result, the following potential positive environmental impacts can be identified:

1. reducing the amount of landfilled organic waste;

2. saving fossil fuels for energy purposes and reduction of $\mathrm{CO}_{2}$ emissions due to production of energy from renewable sources;

3. saving natural resources and valuable elements such as phosphorus for the production of fertilisers.

An analysis of the monthly amount of waste produced by the PISCIS company varies depending on the business model adopted. In one scenario, PISCIS considers that the company will breed and sell whole fish. As a result, waste from this production component is wastewater from biofloc tanks and dead fish. An additional source of fish residue is waste from the production of oil from tilapia's viscera. So far, the company has been collecting the viscera of tilapia from nearby fishing companies. In the second scenario, fish farming is planned, followed by filleting, which entails a significant increase in amounts of fish waste. Implementation of the WtE project by the PISCIS company might significantly reduce the annual amounts of organic wastes by 100.44-189.72 tonnes (depending on the chosen development scenario) [10].

The next result of implementation of the climate-friendly project and technology is the possibility to save fossil fuels for energy purposes as well as reduction of $\mathrm{CO}_{2}$ emissions due to using energy of renewable sources, particularly thanks to establishing micro biogas plants. For the PISCIS company, implementation of the WtE project will determine biogas production in the amount of approximately $6 \mathrm{~m}^{3} /$ day to $125-140 \mathrm{~m}^{3} /$ day depending on the applied approach, with a content of methane at a level of $60-65 \%$, which corresponds to electricity and heat or cold production. The efficiency of the cogeneration unit within the most profitable scenario is approximately $31 \%$, and about $6-7 \%$ of energy produced is considered to be used for biogas installation for own needs. The cold production, within one of the scenarios is approx. 26,499 kWh with thermal efficiency of cogeneration unit of $34 \%$. The main goal of the WtE project is organic waste utilisation, although the saving of resources and $\mathrm{CO}_{2}$ emission avoided are the important results of implementation of the biogas installation as well. Within many of the $\mathrm{WtE}$ projects based on organic waste processing, the production of digestate is present. The average dry matter content can be $4 \%$. If biogas production is based on agricultural organic waste, the produced digestate can be used as fertiliser for agricultural production, bringing benefits for the neighbouring rural territories and improving the environment by replacing the use of artificial fertilizers. The most important 
effects, related to the use of digestate, are its impact on the increase in the yield of plants fertilised with digestate, which will improve the economic results of agricultural activity and additional reduction of the need for mineral fertilisers. This in turn reduces the costs of vegetable or crop production. Simultaneously, the use of digestate reduces the expenditure incurred on agriculture production carried out on the farms

Finally, implementation of the climate-friendly projects of the biogas production installation in the SMEs in Ceara Region, Brazil, can serve as an example of a tool for mitigation of climate change, better management of organic waste and increase of energy efficiency.

\section{References}

[1] J. N. B. Campos, F. A. Souza Filho, and H. V. C. Lima, "Risks and uncertainties in reservoir yield in highly variable intermittent rivers: case of the Castanhão Reservoir in semi-arid Brazil," Hydrol. Sci. J., vol. 59, no. 6, pp. 1184-1195, 2014.

[2] K. E. Kemper, W. Blomquist, and A. Dinar, "River Basin Management at the Lowest Appropriate Level: When and Why Does It (Not) Work in Practice?," in Integrated River Basin Management through Decentralization, 2007, pp. 3-15.

[3] "Portal Hidrológico do Ceará," 2019. .

[4] B. P. F. Braga, "Water Infrastucture and Institutional Development in Semi-arid Brazil." Washington, DC, USA, 2005.

[5] A. P. Hurford, I. Huskova, E. S. Matrosov, and J. J. Harou, "Impacts of management options on water deficits, losses and livelihoods in the Jaguaribe basin of North East Brazil," iEMSs 2012 - Manag. Resour. a Ltd. Planet Proc. 6th Bienn. Meet. Int. Environ. Model. Softw. Soc., pp. 2880-2890, 2012.

[6] "Volume do Castanhão aumenta 21\% nesta quadra chuvosa," O POVO, 2019. .

[7] L. D. de Lacerda, J. A. Santos, R. V Marins, and F. A. T. F. Da Silva, "Limnology of the largest multi-use artificial reservoir in NE Brazil: The Castanhão Reservoir, Ceará State," An. Acad. Bras. Cienc., vol. 90, no. 2, pp. 2073-2096, 2018.

[8] "Mortandade de peixe gera prejuízo de R\$ 18 milhões no Castanhão, no CE," 2015. .

[9] Federation of Industries of the State of Ceará, "Cooperação Técnica Ceará - Polônia," 2019.

[10] PISCIS, "Mapping of relevant information and initial assessment of PISCIS Company," 2019.

[11] R. Massey, J. Lory, and D. Shanklin, "Economic Feasibility of Impermeable Lagoon Covers," no. April 2002.

[12] P. Pędziwiatr, D. Zawadzki, and K. Michalska, "Aquaculture waste management," Acta Innovations, no. 22, pp. 20-29, 2017.

[13] C. Silva Filho, "Waste management in Brazil - it is time to focus on waste as a resource," 2011.

[14] Civil House, National Solid Waste Policy - Brazil. 2010, p. 22.

[15] C. S. Filho et al., "Waste management in Brazil - it is time to focus on waste as a resource," 2011. .

[16] Federation of Industries of the State of Ceará, "Waste management," 2019.

[17] N. Briner, "Biogas Market Analysis," 2011.

[18] Agência Nacional de Energia Elétrica, "Bandeiras tarifárias," 2019. .

[19] US Energy Information Administration, “Country Analysis Executive Summary : Brazil," 2019.

[20] V. de S. Dias, M. P. da Luz, G. M. Medero, and D. T. F. Nascimento, "An overview of hydropower reservoirs in Brazil: Current situation, future perspectives and impacts of climate change," Water (Switzerland), vol. 10, no. 5, 2018.

[21] ClBiogas, “Map Biogas,” 2019. .

[22] Federation of Industries of the State of Ceará, "Ceará - Energy Supply System," 2019.

[23] L. M. Guido Roberto do Rêgo Cavalcanti Júnior, Brazil State Tax on Electrical Energy - ICMS Constitutional, Legal and Regulatory Aspects and the Judicial Decisions about the ICMS Incidence, The George. Washington: School of Business, 2014.

[24] C. Tricase and M. Lombardi, "Environmental analysis of biogas production systems," Biofuels, vol. 3, no. 6, pp. 749-760, 2012. 